\title{
Alt Üriner Sistem Semptomları ile Serum PSA Seviyeleri ve Histolojik Prostatit Arasındaki İlişki
}

\author{
The Relationship Between Histologic Prostatitis and Serum PSA Levels \\ and Lower Urinary Tract Symptoms
}

\author{
Fatih Fırat' ${ }^{1}$, Fikret Erdemir², Engin Kölükçü², Doğan Atılgan², Bekir Süha Parlaktaş², Nihat Uluocak ${ }^{2}$
}

${ }^{1}$ Tokat Devlet Hastanesi, Üroloji bölümü, Tokat
${ }^{2}$ Gaziosmanpaşa Üniversitesi, Tıp Fakültesi Üroloji AD., Tokat

\section{ÖZET}

Amaç: Bu çalışmanın amacı histolojik olarak tespit edilen prostatik inflamasyonun serum PSA seviyeleri ve alt üriner sistem semptomları üzerine olan etkilerini araştırmaktı.

Gereç yöntem: Ocak 2005 ve Ocak 2012 tarihleri arasında transrektal ultrasonografi eşliğinde prostat biyopsisi yapılan toplam 546 hasta retrospektif olarak incelendi. Hastalar, histolojik olarak prostatik inflamasyon tespit edilenler (Grup 1: 333) ve sadece benign prostatik hiperplazi tespit edilenler (Grup 2: 213) olmak üzere kendi içerisinde 2 gruba ayrıldılar. Gruplar, serum PSA seviyeleri ve alt üriner sistem semptomları açısından aralarında karşılaştırıldılar. Alt üriner sistem semptomlarını değerlendirmek için Uluslararası Prostat Semptom Skoru (IPSS) kullanıldı. Semptomlar hafif ( 0-7), orta (8-19) ve şiddetli (20-35) olmak üzere skorlandı.

Bulgular: Hastaların yaş ortalamaları grup 1 ve grup 2 için sırasıyla $64.86 \pm 7.86$ ve $63.69 \pm 7.89$ yıl idi ( $p>0.05$ ). Ortalama PSA değerleri grup 1 'de $10.32 \pm 8.39$ iken grup 2 'de $9.63 \pm 9.69$ olarak tespit edildi $(p=0.016)$. IPSS skorları grup 1 ve 2 için sırasıyla $15.52 \pm 5.76$ ve $13.46 \pm 6.04$ olarak saptandı $(p<0.001)$.

Sonuç: Bu bulgulara göre kronik prostatik inflamasyonun (Tip 4), alt üriner sistem semptomları ile ilişkili olabileceğini söyleyebiliriz. Ayrıca prostat biyopsilerinde saptanan histolojik prostatik inflamasyonun serum PSA seviyeleri üzerine etki ettiği anlaşılmaktadır.

Anahtar kelimeler: prostatik inflamasyon, biyopsi, prostat spesifik antijen, AÜSS

\section{ABSTRACT}

Aim: The aim of this study is to evaluate the effect of histologically diagnosed prostatic inflammation on serum prostatic specific antigen (PSA) levels and lower urinary tract symptoms.

Material and Methods: Between January 2005 and January 2012 a total of 546 patients who underwent transrectal ultrasound guided prostate biopsy were evaluated retrospectively. The patients were divided into two groups are as follows; Group $1(n=333)$ : Histologically detected prostatic inflammation group and group $2(n=213)$ only benign prostatic hyperplasia group. The serum PSA levels and lower urinary tract symptoms were compared between the groups. To evaluate the lower urinary tract symptoms International Prostate Symptom Score (IPSS) was used. Scores of 0 to 7, 8 to 19 , and 20 to 35 represent mild, moderate, and severe symptoms, respectively.

Results: The mean age of the patients was $64.86 \pm 7.86$ years and $63.69 \pm 7.89$ years in group 1 and in group 2 , respectively $(p>0.05)$. The mean PSA values were detected as $10.32 \pm 8.39$ and $9.63 \pm 9.69$ in group 1 and group 2 , recpectively $(p=0.016)$. IPSS scores were $15.52 \pm 5.76$ and $13.46 \pm 6.04$ in group 1 , and in group 2 , respectively $(p<0.001)$.

Conclusion: According to these results we can say that chronic prostatic inflammation (type 4) may be related with lower urinary tract symptoms. In addition, it is understood that histologic prostatic inflammation which was detected by prostatic biopsies effect on serum PSA levels. LUTS

Keywords: Prostatic inflammation, biopsy, prostate specific antigen, 


\section{Giriş}

Illk olarak 1838 yılında Verdes tarafından patoloji olarak tanımlanan prostatit, kelime anlamı olarak prostat bezinin inflamasyonu olsa da geleneksel olarak üriner sistem semptomları, enflamasyon, prostat kökenli ağrı ve etiyopatogenezi tam olarak anlaşılamayan klinik tabloyu ifade etmek için kullanılmaktadır(1). Bu hastalığın nedenleri, uygulanan tedaviler ve etiyopatogenezi hala tartışmalı olup olguların ancak \%5-10'unda etken patojenin gösterilebilmesi, klinik olarak prostatit tanısı konulan hastaların bir kısmının histolojik incelemelerinde prostatit tanısının gösterilememesi ya da histolojik olarak prostatit tanısı konulan hastaların bir kısmında hiçbir klinik yakınmanın olmaması henüz tam olarak açıklanamamıştır. Tüm yaş gruplarında \%8-14 oranında saptanan prostatitler 50 yaş altında en sık, 50 yaş üzerinde ise benign prostat hiperplazisi (BPH) ve prostat kanseri sonrası üçüncü sıklıkta tanı konulan üriner sistem hastalığıdır(2). Otopsi serilerinde bile, bilinen prostat hastalığı olmayanlarda \%44-51 oranında prostatit saptandığı bildirilmektedir(3,4). Ulusal Sağıık Enstitüsü tarafından (NIH) 1998 yılından itibaren akut bakteriyel prostatit, kronik bakteriyel prostatit, kronik pelvik ağrı sendromu (tip 3 kronik prostatit) ve asemptomatik inflamatuvar prostatit (tip 4 kronik prostatit/ histolojik prostatit) olmak üzere dört gruba ayrılarak tanımlanmıştır(5).

Kategori 4 herhangi bir yakınması olmayanlarda, dolayısıyla infertilite ya da prostat kanseri araştırması için yapılan biyopsi incelemelerinde semende ya da prostatik histolojik örneklerde lökosit veya bakteri bulunmasıdır. Literatürde, kronik prostatik inflamasyonlu bireylerde uluslararası prostat semptom skoru (IPSS) skoru ve prostat spesifik antijen (PSA) düzeylerinin, kronik prostatik inflamasyon olmayanlarla karşılaştırılması ile ilgili sınırlı sayıda çalışma vardır.

$\mathrm{Bu}$ çalışmada, kliniğimize başvuran hastalar arasında prostat kanseri araştırması için yapılan incelemelerde tip 4 kronik prostatit tanısı konulan erkek olgularda histolojik olarak tespit edilen prostatik inflamasyonun serum PSA seviyeleri ve alt üriner sistem semptomları üzerine olan etkileri değerlendirildi.

\section{GEREÇ VE YÖNTEM}

Ocak 2005 ve Ocak 2012 tarihleri arasında transrektal ultrasonografi eşliğinde prostat biyopsisi yapılan toplam 546 erkek hasta retrospektif olarak incelendi. Hastalar, histolojik olarak kronik prostatik inflamasyon tespit edilenler (Grup 1: 333) ve sadece benign prostatik hiperplazi tespit edilenler (Grup 2: 213) olmak üzere 2 gruba ayrıldılar. Gruplar, serum PSA seviyeleri ve alt üriner sistem semptomları açısından aralarında karşılaştırıldılar. Hastalar kliniğimizde, ayrıntılı öykü, tam idrar tetkiki, parmakla rektal muayene, rutin hematolojik ve biyokimyasal tetkikler, idrar akım hızı, üriner ultrasonografi ile değerlendirildiler. Alt üriner sistem semptomlarını değerlendirmek için Uluslararası Prostat Semptom Skoru (IPSS) kullanıldı. Semptomlar hafif ( 0-7), orta (8-19) ve şiddetli (2035) olmak üzere skorlandı. Çalışmamıza nörolojik hastalığı olanlar, üretra darlığı olanlar, kronik karaciğer, böbrek yetmezliği ve diabetes mellitus gibi kronik sistemik bir hastalığı olan olgular, geçirilmiş pelvik cerrahi öyküsü olanlar, daha önceden psikiyatrik bozukluk tanısı ile antidepresan, antipsikotik ve anksiyolitik ilaç alan olgular ile antikonvülzan gibi kronik ilaç tedavisi alan olgular ve yakın zamanda geçirilmiş üriner trakt infeksiyonu olan olgular dahil edilmedi.

Sonuçların karşılaştırılmasında bağımsız iki örneklem $t$ testi kullanıldı. $\mathrm{P}<0.05$ değeri istatistiksel olarak anlamlı kabul edildi. İstatistiksel değerlendirme SPSS $19^{\circledR}$ programı ile yapıldı.

\section{BULGULAR}

Hastaların yaş ortalamaları grup 1 ve grup 2 için sırasıyla $64.86 \pm 7.86$ yıl ve $63.69 \pm 7.89$ yıl idi. Yaş yönünden gruplar arasında istatistiksel olarak anlamlı fark bulunmadı $(p=0.089)$. Ortalama PSA değerleri grup 1 'de $10.32 \pm 8.39 \mathrm{ng} / \mathrm{mL}$ olarak tespit edilirken grup 2'de $9.63 \pm 9.69 \mathrm{ng} / \mathrm{mL}$ olarak tespit edildi ( $p=0.016)$. IPSS skorları grup 1 ve 2 için sırasıyla $15.52 \pm 5.76$ ve $13.46 \pm 6.04$ olarak saptandı $(p<0.001)$. Histolojik olarak BPH ve kronik prostatit tanısı konulan hastalarda PSA ve IPSS yönünden istatistiksel olarak anlamlı fark saptandı (sırasıyla $p=0.016$ ve $p<0.001$ ) (Tablo 1 ). 
Tablo 1. Olguların klinik özellikleri.

\begin{tabular}{|c|c|c|c|c|c|}
\hline & \multicolumn{2}{|c|}{ BPH $(n=213)$} & \multicolumn{2}{|c|}{ Kronik Prostatit $(n=333)$} & \multirow[b]{2}{*}{$\mathbf{p}$} \\
\hline & Ort $\pm S S$ & Min-Max & Ort $\pm S S$ & Min-Max & \\
\hline YAŞ & $63.69 \pm 7.89$ & $42-83$ & $64.86 \pm 7.86$ & $39-82$ & 0.089 \\
\hline PSA & $9.63 \pm 9.69$ & $1-74$ & $10.32 \pm 8.39$ & $1-68$ & 0.016 \\
\hline IPSS & $13.46 \pm 6.04$ & $1-29$ & $15.52 \pm 5.76$ & $2-34$ & $<0.001$ \\
\hline
\end{tabular}

\section{TARTIŞMA}

Prostat Spesifik Antijen prostat kanserinin tanısında yararlanılan serum belirtecidir ve genellikle rektal tuşe ile birlikte prostat kanserinin erken değerlendirmesinde kullanılır. Diğer yandan PSA organa spesifik olup kansere spesifik olmadığından BPH, prostatit, prostatik infarkt, akut üriner retansiyon, prostat biyopsisi, sistoskopi, üretral kateterizasyon ejekülasyon ve prostata yönelik operasyonlar gibi birçok nedene bağlı olarak yükselebilmektedir(6). Prostatitlerdeki PSA yüksekliğinin patofizyolojisi net olarak tespit edilememiş olsa da prostat dokusu ve kan arasındaki doğal anatomik ve fizyolojik bariyerlerin bozulması olasılığı önemli bir faktördür(7). Akut prostatit sonrası hastaların büyük bir kısmında (\%71-90) serum PSA düzeylerinin arttığı bilinmektedir. Bu oran kategori 2'de \%15-20 ve kategori 3'te ise \%6-28.5 olarak bilinmektedir. Kategori IV'teki hastaların değerlendirildiği bir çalışmada hastaların \%40'ında serum PSA düzeylerinin yüksek olduğu saptanmıştır(8). Kategori IV'te infeksiyon şiddeti ile PSA arasında ilişki olup olmadığı ile ilgili farklı sonuçların elde edildiği çalışmalar vardır. Affonso Celso Piovesan ve ark tarafından yapılan bir çalışmada histolojik prostatit tanısı konulmuş 143 hasta ile BPH tanısı konulmuş 38 hasta grupları kendi aralarında serum PSA dansitesi açısından karşılaştırıldığında istatistiksel olarak anlamlı bir fark saptanmadığı bildirilmiştir(9). Prostatik inflamasyonun potansiyel nedenlerinden bazıları direk infeksiyon, idrar reflüsü, beslenme faktörleri, östrojen veya bunların kombinasyonlarıdır(10). Belirtilen bu ve benzeri nedenlerin prostatta serbest radikallerin meydana gelmesine ve bunun sonucu olarak ta oksidatif hasarın ortaya çıkmasına neden olduğu dolayısıyla prostat dokusunda hasara neden olduğu bildirilmiştir(10). Literatürde KP'te inflamasyonun şiddeti ile serum PSA arasında ilişki bulunmadığını bildiren çalışma bulunmasına rağmen ülkemizde Yaman ve ark.'nın yapmış oldukları çalışmada prostattaki inflamasyonun derecesi ile PSA yüksekliğinin ilişkili olduğu gösterilmiştir(11). Öte yandan bir başka çalışmada asemptomatik olgularda prostat kanseri için TRUS biyopsi yapılması sonrası prostatit tanısı histolojik olarak konulan hastalar, inflamasyonun şiddetine göre 3 gruba ayrılmışlar. Buna göre inflamasyonun \%20'den az olduğu hastalar grup 1 'i, \%20-50 arasında olanlar grup 2'yi ve \%50'nin üzerinde olanlarda grup 3'ü oluşturmuşlardır. Bu çalışmada serum PSA değerleri sırası ile $4.96 \mathrm{ng} /$ $\mathrm{ml}, 7.40 \mathrm{ng} / \mathrm{ml}, 8.03 \mathrm{ng} / \mathrm{ml}$ olarak saptanmıştır. Prostatitli olgularda artmış PSA düzeyinin fizyopatolojisi net olarak açıklanamamıştır. Klinik olarak prostat kanseri saptanmayan hastalarda serum PSA seviyelerinin yüksekliğinde prostatik inflamasyonun önemli rolü olduğu gösterilmiştir. Prostat volümü ve inflamasyonun PSA yüksekliğindeki rolü sırası ile $\% 23$ ve $\% 7$ olarak bulunmuştur(12). BPH'lı hastalarda herhangi bir klinik bulgu saptanmadan prostatit ve PSA seviyeleri arasında pozitif korelasyon tarif edilmiştir(7). Van vuuren ve arkadaşları tarafından yapılan bir çalışmada 204 hasta değerlendirildiğinde histolojik olarak BPH ve prostatit tanısı konulanlarda PSA seviyelerin ortalaması sırasıyla 14.6 ve $22.8 \mathrm{ng} / \mathrm{mL}$ olarak tespit edildiği ve bunun istatistiksel olarak anlamlı olduğu bildirilmiştir(13). Igor stancik ve arkadaşları tarafından 404 hastaya yapılan biyopsi sonrası hastaların 137 sinde tip 4 prostatit, 143 ünde $\mathrm{BPH}, 100$ tanesinde ise prostat ca tanısı konulmuş ve bu hastalarda serbest ve total PSA seviyeleri ölçülerek kendi aralarında karşılaştırılmıştır. Tip 4 kronik prostatitin serum serbest ve total psa seviyelerini prostat $\mathrm{Ca}$ dakine benzer şekilde etkilediği, serbest / total PSA oranlarının ise prostat ca ve tip4 kronik pros- 
tatitte önemli derecede farklı olduğu sonucuna varılmıştır(14). Bütün bu bulgular, prostatik inflamasyonun PSA artışında rolü olduğunu göstermektedir. Çalışmazda da literatürdeki ile uyumlu olarak, histolojik olarak prostatit tanısı konulan hastaların serum psa seviyeleri ile histolojik olarak yalnızca bph tanısı alan hastaların serum psa seviyeleri karşılaştırıldığında; prostatit tanısı alan hastalarda psa seviyelerinin istatistiksel olarak anlamlı şekilde artmış olduğu gözlendi $(p=0.016)$

Benign prostat hiperplazisi yaşlanan erkeklerde alt üriner sistem semptomları (AÜSS)'nın sıklığından dolayı önemli bir yük oluşturmakta ve sıklıkla yaşam kalitesini bozabilmektedir. Bazı erkeklerin hastalığı progresiftir yani IPSS skorunda artma veya akut üriner retansiyon ya da BPH ile ilgili cerrahi geçirebilmektedirler. Temel değerler; örneğin yaş, yaygın AÜsS, düşük pik akım değeri, yüksek işeme sonrası hacim ve büyümüş prostat hacmi bazı çalışmalarda AUR ve BPH la ilişkili cerrahi açısından risk faktörü olarak tariflenmiştir(15). Fakat kronik inflamasyonun $\mathrm{BPH}$ progresyonuna etkisi ile ilgili literatürde sInırlı sayıda çalışma mevcuttur. Alt üriner sistem semptomlarının ilerlemesinde kronik inflamasyonun rolünü araştırmak için literatürü gözden geçirdiğimizde; Serum PSA seviyesi yüksekliği nedeniyle biyopsi yapılan ve histolojik incelemesi benign olarak rapor edilen, 5597 hastanın alındığı bir çalışmada kronik prostatik inflamasyon oranı \%78 olarak bildirilmiştir. Aynı çalışmada inflamasyon derecelendirilmiş ve inflamasyon oranı ile alt üriner sistem semptomlarının şiddeti arasında pozitif korelasyon saptanmıştır(16). Benzer şekilde Medical Treatment of Prostatic Symptoms (MTOPS) çalışmasında, tedavi öncesi prostat biyopsilerinde 1197 bireyin \%43 ünde kronik prostatit saptanmıştır(15). Yapılan değerlendirmenin sonuçları, histolojik inflamasyonun $\mathrm{BPH}$ progresyonu açısından risk faktörü oldu- ğunu destekler nitelikte görünmektedir. İnflamasyon olan bireylerde olmayanlara göre klinik progresyon (cerrahi girişim gerekliliği, semptom artışı, akut idrar retansiyonu) olasılığı daha yüksek olarak bildirilmiştir. Kronik inflamasyonlu hastalar için cerrahi gerekliliği ve klinik progresyon sırasıyla \%5.6 ve \%21'dır. Bu oranlar inflamasyon olmayan bireylerde sırasıyla \%13.1 ve \%3.9'dur. Prostat inflamasyonu olmayan bireylerde çalışma boyunca hiç akut idrar retansiyonu olmazken inflamasyonlu hastalardaki akut retansiyon oranı \%7.3'olarak bildirilmiştir ( $p=0.003$ ) (15). Mishra ve arkadaşları tarafından BPH cerrahisi geçiren hastalarla yapılan bir çalışmada ağır semptomlu (üriner retansiyon) hastalarla daha hafif semptomlu (retansiyonda olmayıp AÜS yakınmaları nedeniyle cerrahi yapılan) bireyleri karşılaştırdıklarında ağır semptomlu olgularda daha yüksek oranda histolojik inflamasyon saptamışlardır (\%70'e karşı \%45) (17). Çalışmamızda da histolojik olarak prostatit tanısı konulan hastaların alt üriner sistem semptomları ile histolojik olarak yalnızca bph tanısı alan hastaların alt üriner sistem semptom seviyeleri karşılaştırıldığında; kronik prostatik inflamasyon (Tip 4) tanısı alan hastalarda alt üriner sistem semptomlarının istatistiksel olarak anlamlı şekilde artmış olduğu gözlendi $(p<0.001)$.

Bu bulgulara göre kronik prostatik inflamasyonun (Tip 4), alt üriner sistem semptomları ile ilişkili olabileceğini söyleyebiliriz. Ayrıca prostat biyopsilerinde saptanan histolojik prostatik inflamasyonun serum PSA seviyeleri üzerine etki ettiği anlaşılmaktadır. Bununla birlikte bu sonuçların değerlendirilebilmesi için gelecekte daha spesifik olgu gruplarının olduğu çalışmaların gerek klinik gerekse de patofizyolojik olarak belirli mekanizmaların ortaya konulması için yapılması gerektiğini belirtebiliriz. 


\section{KAYNAKLAR}

1. Erdemir F, Parlaktaş BS, Uluocak N. "Prostatitlerin Patofizyolojisi, Tanısı, Tedavisi ve Değerlendirilmesindeki Yenilikler," Üroloji Bülteni, 2007; 18: 147-155

2. 2. Nickel JC: Prevalence of Prostatitis Like Syndromes in a Population Based Study Using the National Institutes of Health Chronic Prostatitis Symptom Index. J Urol, 2001; 165: 842-845

3. McNeal JE. Regional morphology and pathology of the prostate. Am J Clin Pathol. 1968 ; 49:347-57

4. Xie H, Huang HC, Yang YR et al. Expressions of bacterial 16S rRNA, IL-1beta, TNF-alpha and NGF in prostate tissues. Zhonghua Nan Ke Xue. 2010; 16: 40-3

5. Krieger JN, Nyberg L Jr, Nickel JC. NIHconsensus definition and classification of prostatitis. JAMA 1999; 282:236-237

6. Cuneyt Ozden, Levent Ozdal, Ozer Guzel et al. The correlation between serum prostate specific antigen levels and asymptomatic inflammatory prostatitis Int Urol Nephrol 2007; 39:859-863

7. 7. Hasui Y, Marutsuka K, Asada Y. et al. Relationship between serum prostate specific antigen and histological prostatitis in patients with benign prostatic hyperplasia. Prostate. 1994; 25: 91-6

8. Sciarra A, Di Silverio F, Salciccia S et al. Inflammation and chronic prostatic diseases: evidence for a link? Eur Urol. 2007; 52: 964-72

9. Piovesan AC, Freire Gde C, Torricelli FC et al. Incidence of histological prostatitis and its correlation with PSA density. Clinics (Sao Paulo). 2009; 64: 1049-51.
10. De Marzo AM, Nakai Y, Nelson WG. Inflammation, atrophy, and prostate carcinogenesis. Urol Oncol. 2007; 25: 398-400

11. Yaman O, Göğüş C, Tulunay O et al. Increased prostate-specific antigen in subclinical prostatitis: the role of aggressiveness and extension of inflammation. Urol Int. 2003; 71: 160-4.

12. Nadler RB, Humphrey PA, Smith DS et al. Effect of inflammation and benign prostatic hyperplasia on elevated serum prostate specific antigen levels. J Urol. 1995; 154: 407-13.

13. van Vuuren SP, Heyns CF, Zarrabi AD. Significance of histological prostatitis in patients with urinary retention and underlying benign prostatic hyperplasia or adenocarcinoma of the prostate. BJU Int. 2012; 109: 1194-7. See comment in PubMed Commons below

14. Stancik I, Lüftenegger W, Klimpfinger M. et al. Effect of NIH-IV prostatitis on free and free-to-total PSA. Eur Urol. 2004; 46: 760-4.

15. Roehrborn CG. Definition of at-risk patients: baseline variables. BJU Int 2006; 97: 7-11.

16. Nickel JC, Roehrborn CG, O'leary MP et al. Examination of the relationship between symptoms of prostatitis and histological inflammation: baseline data from the REDUCE chemoprevention trial. J Urol. 2007; 178: 896-900

17. Mishra VC, Allen DJ, Nicolaou C et al. Does intraprostatic inflammation have a role in the pathogenesis and progression of benign prostatic hyperplasia? BJU Int. 2007; 100: 327-31. 